\title{
„Heel vibrating device”- egy új eszköz a térdízületi flexiós kontraktúra megelőzésére térdízületi endoprotézis beültetést követően
}

\author{
DR. GYŐRFI GYULA ${ }^{1}$ DR. SZABÓ JÁNOS ${ }^{1}$, KÓSA VERONIKA ${ }^{1}$, \\ MANÓ SÁNDOR ${ }^{2}$, DR. CSERNÁTONY ZOLTÁN ${ }^{1}$
}

\section{ÖSSZEFOGLALÁS}

Totál térdízületi protézis beültetés után előforduló egyik lehetséges szövődmény az ízületben kialakuló flexiós kontraktúra. A szerzők egy olyan, általuk „heel vibrating device”-nak nevezett eszközt fejlesztettek ki és vezettek be a klinikai gyakorlatba, mely a sarok alátámasztásával, vertikális irányú harmonikus rezgőmozgást végezve segít a térdprotézis beültetés utáni posztoperatív flexiós kontraktúra megelőzésében. Az eredményeket a közvetlen posztoperatív és a hazabocsátáskor készített, oldalirányú röntgenfelvételeken mért extenziós szögértékek alapján értékelték. A vizsgálat eredményei biztatóak, szerzők jelenleg is rutinszerűen alkalmazzák az eszközt a klinikai gyakorlatban.

\section{Kulcsszavak: $\quad$ Arthroplastica; Contractura; Continous Passive Motion; Mozgásterápia;} Mozgásterjedelem; Térdízület; Vibráció;

Gy. Györfi, J. Szabó, V. Kósa, Z. Csernátony, S. Manó: „Heel vibrating device” - a new method to prevent flexion contracture of the knee joint after knee replacement

Flexion contracture is a frequent complication after total knee replacement. Authors developed and introduced a new device in clinical treatment, which is supporting the heel, vibrating in vertical direction, therefore helps to prevent flexion contracture. The results were evaluated by measuring the angles of knee extension on postoperative lateral view X-ray, and an X-ray before discharging the patient. Their initial results are encouraging. They are treating patients with this method in everyday practice.

\section{Keywords: $\quad$ Arthroplasty, replacement, knee - Rehabilitation;}

Contracture - Prevention \& Control; Knee Joint - Physiopathology;

Motion therapy, Continuous Passive; Range of motion, articular;

Vibration - Therapeutic use; 


\section{BEVEZETÉS}

A primer totál térdprotézis beültetésen átesett betegek hosszú távú funkcionális eredményeit döntően befolyásolja a közvetlen posztoperatív szakban végzett rehabilitáció. Fő célunk, hogy a beteg hazabocsájtásakor a lehető legjobb mozgástartományt érjük el az operált térden, de néhány esetben ez mégsem kivitelezhető, túlnyomórészt kisebb-nagyobb flexiós kontraktúra kialakulása miatt (1). A korai flexiós kontraktúra annak ellenére is kialakulhat, hogy a térdízület protetizálása során minden esetben teljes extenziót érünk el a mútőasztalon. Ennek több oka is lehet. Leggyakoribb a fájdalom kiváltotta reflexes izomvédekezés, melynek eredményeként a térden tartós szemiflektált antalgiás tartás alakul ki. Mozgásbeszűkülést okozhat a protézis komponenseinek malpozíciója is, amely azonban eltérő kezelést igényel, melynek tárgyalása meghaladja a közlemény kereteit. A teljes extenzió elmaradásának legnagyobb problémája, hogy folyamatos munkára kényszeríti a quadriceps és a flexor izomzatot álló testhelyzetben, ezáltal azok korai kifáradásához, fájdalmához vezet. A patellofemoralis ízület terhelése is jelentősen nő (3), valamint a későbbiekben a lágyrészegyensúly megbomlása miatt nagyobb az esélye az ízületi instabilitás kialakulásának $(6,7)$.

A legfőbb problémát az jelenti, hogy a tartósan flektált helyzetben tartott térdben idővel a passzív stabilizátorok is zsugorodnak, kialakul az artrogén kontraktúra (9), melynek oldása jóval nehezebb, gyakran mútétet igénylő feladat.

A térdízületi protézis mútöttek rehabilitációjában a legelterjedtebben használt eszköz a Salter (8) által bevezetett mozgatókészülék (közismert nevén CPM - continuous passive motion), melynek flexióra gyakorolt kedvező hatását számos tanulmány igazolta, de az extenzióra kifejtett hatása vitatható (11). A készülék alkalmazása során ugyanis az elért extenziót jelentősen befolyásolja a beteg ágyban elfoglalt pozíciója, így előfordulhat, hogy a térd akár 20 fokos flektált helyzetben marad 0 fokos extenzió beállítása esetén is.

Célunk egy olyan eszköz kifejlesztése volt, aminek rendszeres alkalmazása a mútét végén elért teljes extenzió fenntartásához hozzájárulhat. A koncepciónk: az operált végtag sarkát alátámasztjuk, felfelé tekintő patellával, az alátámasztott sarkat pedig vertikális irányban harmónikus rezgőmozgást végezve mozgatjuk állítható amplitúdóval és frekvenciával. A térd haránt tengelye merőleges a mozgató erőre, így a végtag tehetetlenségénél fogva a térd zsugorodásra hajlamos hátsó képleteinek repetitív nyújtása következik be.

\section{Anyag és módszer}

A DEKK Ortopédiai Klinikán, primer totál térdprotézis beültetésen átesett betegeket kezeltünk az általunk kifejlesztett és elnevezett „heel vibrating device" (HVD) készülékkel 2012. júniustól 2012. decemberig, majd egy későbbi vizsgálat során annak továbbfejlesztett változatával 2013. júniustól 2015. szeptemberig (etikai engedély száma: RKEB/IKEB-Prot. No. 2789-2008) (4, 10).

Az eredeti készülék felépítése a következő: az eszköz egy „alaptestből” és egy azon rögzített saroktartóból áll. A saroktartóba tépőzárral lehet rögzíteni a lábat, biztosítva ezzel a rotációs középhelyzetet a kezelés során. $\mathrm{Az}$ alaptesten egy karral állítható a mozgás amplitúdója, mely 0,5 és $3 \mathrm{~cm}$ értékek között változtatható (1. ábra).

Az „alaptesthez” csatlakoztatott vezérlo”egységen (1. ábra) található fordulatszám szabályzóval határozhatjuk meg a rezgés frekvenciáját. A vezérlőegységen található továbbá egy funkciókapcsoló, mellyel kézi és gépi vezérlés között választhatunk. Kézi vezérlés során a főkapcsolóval indíthatjuk el és állíthatjuk meg a kezelést, míg számítógépes vezérlés esetén a vezérlőegység bluetooth kapcsolaton keresztül csatlakoztatható egy PDA (personal digital assistant) készülékhez, melyen egy vezérlőszoftver segítségével adhatjuk meg a kezelés paramétereit.

A HVD második változata (2. ábra) kerekeken gurul, így jelentősen könnyebben alkalmazható, hiszen a készüléket visszük a betegágyhoz, azaz úgynevezett bedside kezelést tesz lehetővé. A készülék egyetlen egységből áll, melynek föbb alkatrészei egy tartószerkezet, aminek vízszintes elemére rögzítettük a motort, a motorból kinyúló mozgatórúdra pedig egy lánc segítségével akasztjuk a saroktartó 
szalagot. A kezelés során a HVD-t a betegágy mellé toljuk, majd beállítjuk úgy, hogy a mozgatórúd, a saroktartó szalag középpontja és az abba helyezett végtag sarka egy függőleges vonalban helyezkedjenek el (2. ábra). Azáltal, hogy a saroktartó szalag saját tengelye körül foroghat, egyfajta önbeállási lehetőséget biztosít a végtag számára, eközben a saroktartó szalag a láb és ezen keresztül az alsó végtag rotációját is akadályozza, így a ható erő mindig merőleges a térd haránt tengelyére.

A mozgás amplitúdója itt állandó, a frekvencia változtatható, a gyakorlatban a kezelések időbeli előrehaladtával fokozzuk a frekvenciát. A készülék egy főkapcsolóval hozható múködésbe.

A HVD mindkét verziójával randomizált prospektív, biostatisztikussal előzetesen megtervezett vizsgálat zajlott.

$A$ vizsgálatok során csak primer térdprotézis beültetésen átesett betegeket vizsgáltunk. Kizáró kritérium csak a mútétet követően fellépő, sebgyógyulást befolyásoló szövődmény, valamint olyan esetleges intraoperatív körülmény volt, ami miatt az operatőr a későbbiekben nem kívánta alkalmazni betegénél a készüléket.

Az első készülék hatékonyságának vizsgálatánál a betegeket randomizálva két csoportra osztottuk (144 beteg). Az első csoportban a betegek mútétet követően 7 napig naponta legalább 10 percig használták a HVD készüléket $2 \mathrm{~cm}$-es amplitúdóval és $2 \mathrm{~Hz}$-es frekvenciával. Emellett naponta legalább egy órán át használtak egy speciális, szivacsból kialakított „sarokpárnát” (3. ábra), valamint CPM kezelésben is részesültek.

A „sarokpárna” szintén saját fejlesztésünk, alkalmazásakor a szivacsban kialakított vályúba helyezzük a beteg sarkát, így megőrizhető a gyógytorna vagy HVD kezelést követően elért teljes extenzió (3. ábra). A betegek hajlamosak az operált végtagot a betegágyban kirotált és flektált térddel tartani a fájdalom csökkentése céljából, azonban ez is a teljes extenzió rovására mehet. Ennek kiküszöbölésében segít a „sarokpárna".

A kontroll csoportban a betegek a gyógytorna mellett csak CPM kezelést kaptak.

A második verziójú HVD első vizsgálatánál hasonló randomizálást követően osztottuk két csoportra a betegeket (91 beteg). A kísérleti csoport betegei naponta 10 perc HVD kezelést kaptak - a terápia elejétől a végéig lassan, de fokozatosan emelkedő frekvenciával - a gyógytorna és CPM kezelés mellett. A kontroll csoport betegei ismét CPM és gyógytorna kezelésben részesültek.

A harmadik vizsgálatot megelőzően már minden korábbi tapasztalatot összesítve dolgoztuk ki a protokollt (64 beteg). Ebben már két időszakra osztottuk a kezelést, az első 5 napban az egyik csoport csak CPM, a másik CPM+HVD kezelést kapott, passzív extenziós gyógytorna és sarokpárna nélkül, míg az utolsó két napon szükség esetén passzív extenziós gyógytornát is alkalmaztunk az esetleges reziduális flexiós kontraktúra megszüntetése érdekében.

$\mathrm{Az}$ első és második vizsgálat során posztoperatív 7. napon, a harmadik vizsgálatnál a posztoperatív 1 . és 5 . napon minden betegről oldalirányú térd röntgenfelvétel készült az elérhető teljes extenzióban, mely helyzetet a végtag sarokpárnába történő helyezésével és a térd levegóbe emelésével biztosítottuk. A felvételeken ezt követően meghatároztuk az elért extenziós szög, vagy éppen a kialakult flexiós kontraktúra mértékét. A méréseinket nehezítette, hogy a hagyományos oldalirányú térdfelvételen csak a femur distalis és a tibia proximalis harmada látható (4. ábra). Ennek kiküszöbölésére egy korábbi munkában vizsgáltuk azt, hogy az így készült röntgenen mely anatómiai síkok, egyenesek adhatják meg a térd extenziójának valós mértékét (2). A vizsgálat eredményeként azt találtuk, hogy ezt az értéket a femur distalis végének ventralis kortikálisa és a tibia proximalis végének dorzális kortikálisa által bezárt szög adja meg (5).

Azért, hogy a szögméréshez szükséges egyenesek felvételének szubjektivitását minél inkább kiküszöböljük, a szögméréseket minden esetben különböző munkatársakkal kétszer megismételtük és a három mérés átlagával számoltunk tovább.

$A z$ első vizsgálat értékelésénél a $-5^{\circ}$ (hiperextenzió) és $+5^{\circ}$ (flexió) közötti értékeket soroltuk az elfogadható csoportba, ez alapján végeztük el a kétmintás t-próbát.

A második verzió első vizsgálatánál az elfogadható tartományba csak a teljes extenziót $\left(0^{\circ}\right)$, valamint a bármilyen mértékú hiperextenziót soroltuk, mivel az első vizsgálatnál szerzett tapasztalataink alapján jóval 
pontosabban tudtuk mérni a röntgenfelvételeken a szögértékeket.

A harmadik vizsgálat során a posztoperatív 1. és 5. napon készült röntgenfelvételeken mértük az extenziós szögértéket, az adatok elemzését pedig az értékek változása alapján végeztük el, kétmintás t-próbával.

A próbát az első és harmadik vizsgálatnál 5\%-os szignifikancia szint mellett végeztük, míg a második vizsgálatnál 5 és 10\%-os szignifikancia szint mellett is.
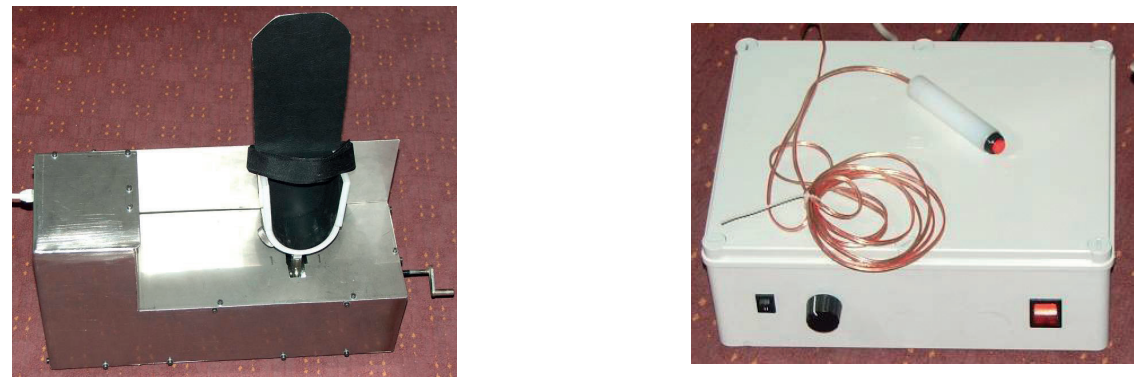

1. ábra A HVD készülék első változata
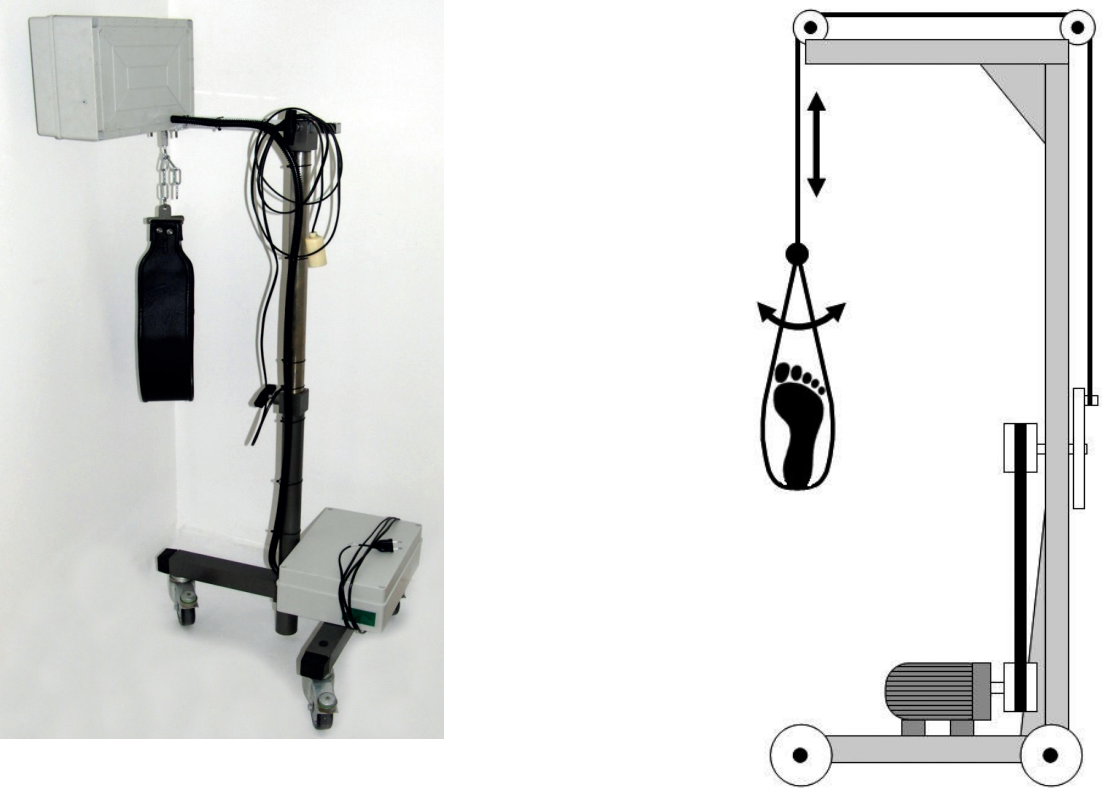

2. ábra A HVD készülék továbbfejlesztett változata

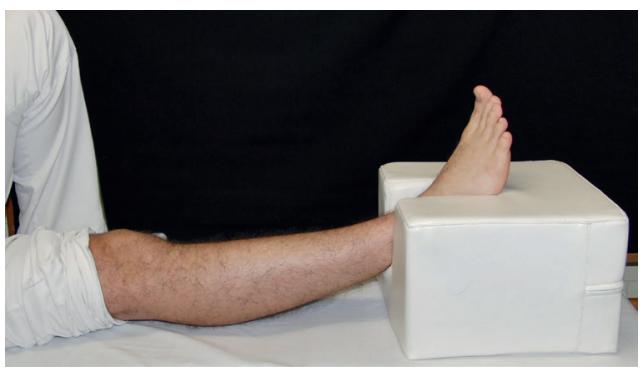

3. ábra $A$,sarokpárna” használata 


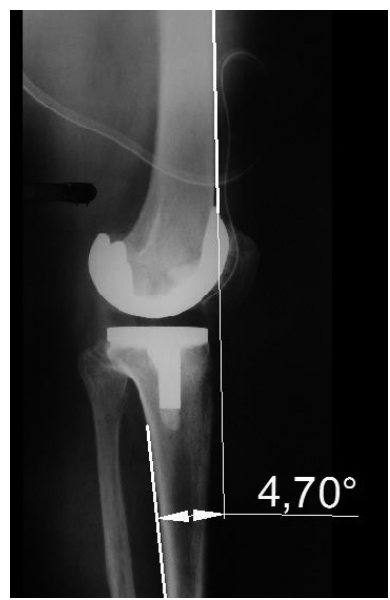

4. ábra Az extenzió meghatározása oldalirányú térd röntgenfelvételen

\section{Eredmények}

Az első HVD készülék vizsgálatakor az I. táblázatban látható eredményeket kaptuk.

A minta alapján a nullhipotézis, miszerint a két csoportban ugyanannyi esetben mérhető hazaengedéskor $-5^{\circ}$ és $+5^{\circ}$ közötti flexiós szög, 5\%-os szignifikanciaszint mellett egyoldali, kétmintás aránypróbával elutasításra került (szignifikancia=0,0355).

A második verziójú HVD készülék első vizsgálatakor a II. táblázatban feltüntetett értékeket kaptuk.

A minta alapján a nullhipotézis, miszerint a két csoportban ugyanannyi esetben mérhető hazaengedéskor $0^{\circ}$ vagy annál kisebb szög, csak $10 \%$-os szignifikanciaszint mellett került egyoldali, kétmintás aránypróbával elutasításra (szignifikancia=0,08526). A minta alapján a két eljárás között tehát 10 \%-os szignifikancia szint mellett mutatható ki szignifikáns eltérés: a CPM+HVD továbbfejlesztett változatával kezelt csoportban a megfelelőnek mondható szögek aránya nagyobb.

A harmadik vizsgálatnál a csak CPM-mel kezelt csoportban az extenziós szögértéket tekintve összességében átlagosan mintegy $0,85^{\circ}$-os romlás tapasztalható, míg a HVD-vel kiegészített csoportban $2,4^{\circ}$ az átlag javulás. A két csoport eredményei között kétszélű esetben is szignifikáns a különbség 5\%-os szignifikanciaszinten $(p=0,0033)$, azaz a HVD-vel is kezelt csoportban a térd extenziós szögére vonatkozó javulás szignifikánsan nagyobb (III. táblázat).

\section{I. táblázat A statisztikai minta jellemző adatai}

\begin{tabular}{|c|c|c|}
\hline & csak CPM-mel kezelt csoport & $\begin{array}{c}\text { CPM+kiegészítő kezelésben } \\
\text { részesült csoport }\end{array}$ \\
\hline $\mathrm{n}$ (kezeltek száma) & 65 & 79 \\
\hline $\mathrm{k}\left(\mathrm{a}-5^{\circ}\right.$ és $+5^{\circ}$ közé eső szögek \\
száma)
\end{tabular}




\section{II. táblázat A statisztikai minta jellemzö adatai}

\begin{tabular}{|c|c|c|}
\hline $\mathrm{n}$ (kezeltek száma) & 42 & 48 \\
\hline $\mathrm{k}$ (a $0^{\circ}$ és hiperextenzió közé eső szögek száma) & 22 & 31 \\
\hline $\mathrm{p}$ (a 0 és hiperextenzió közé eső szögek aránya) & $52 \%$ & $65 \%$ \\
\hline $\mathrm{p}$ érték $=0,08526$ & & \\
\hline
\end{tabular}

\section{III. táblázat A statisztikai minta jellemző adatai}

n (kezeltek száma)

az 1. és 5. napon mért extenziós szögérték átlagos változása
32

$-0,85^{\circ}$
32

$+2,42^{\circ}$

$$
p \text { érték }=0,0033
$$

\section{Megbeszélés}

A primer térdprotézis mútéten átesett betegek korai mobilizálása, rehabilitációja igen fontos szerepet játszik abban, hogy a beteg a későbbiekben elégedett lesz-e a mútétével. A kórházban töltött időszak alatt arra törekszünk, hogy minél jobb mozgástartományt tudjunk elérni az operált térden a rendelkezésre álló eszközök segítségével. A korai posztoperatív szakban kialakult flexiós kontraktúra $(1,6)$ döntően befolyásolhatja a rövid és hosszú távú eredményeket, valamint tartósan fennálló térdízületi panaszokhoz vezethet, amelyek további kezelést igényelhetnek. Ezek közül legsúlyosabb az artrogén kontraktúra (9), melynek oldása gyakran csak mútéti úton lehetséges, de a tartósan fennálló retropatellaris fájdalom (3) is jelentősen megnehezítheti a betegek hétköznapjait.

A térdprotézis mútét utáni rehabilitációban évtizedek óta használt módszer a CPM kezelés (8), melynek flexióra gyakorolt kedvező hatását számos tanulmány vizsgálta. Extenzióra gyakorolt hatása azonban vitatható (11), nagyrészt azért, mivel a kezelés során optimális esetben is a teljes, $0^{\circ}$-os extenzió érhető el, amenynyiben a készüléket megfelelően pozícionáljuk a kezelés során, ellenkező esetben még az sem.

Célunk egy olyan eszköz kifejlesztése volt, mely a korai posztoperatív szakban térdprotézis beültetésen átesett betegeknél megelőzi a flexiós kontraktúra kialakulását, ezzel párhuzamosan alkalmazva a CPM készüléket pedig a megfelelő flexiót biztosító hatás is éri a térdet. Ennek eredményeként született meg a HVD készülék, majd készült el annak továbbfejlesztett változata, kiküszöbölve az első verzió hibáit, nehézségeit $(4,10)$. Az első készülék múködésének lényege, hogy a saroktartóba helyezett, operált végtag sarkával harmonikus rezgőmozgást végez állítható amplitúdóval és frekvenciával, miközben a patella előre tekint, tehát a térd haránt tengelye vízszintes. Ily módon a mozgás végpontján a végtag saját tehetetlenségénél fogva passzív nyújtó hatást gyakorol a térdízület hátsó képleteire, ezzel elérve a minél teljesebb extenziót.

A HVD készülék továbbfejlesztett változata könnyebben mozgatható, mivel lefékezhető kerekeken gurul. Azzal pedig, hogy a sarok nem egy rigid saroktámaszon, hanem egy saroktartó szalagban nyugszik és a láb rotációs helyzete fix, egyfajta önbeállási lehetőséget biztosít az operált végtag számára a kezelés folyamán úgy, hogy a térd haránt tengelye mindig merőleges legyen a hatóerőre. A készülék rendkívül könynyen, akár a beteg által is múködtethető.

A posztoperatív szakban oldalirányú röntgenfelvételeken határoztuk meg a teljes extenzió szögértékét, az eredmények tekintetében az első változatnál az $-5^{\circ}$ (hiperextenzió) és $+5^{\circ}$ (flexió) közé eső értékeket definiáltuk elfogadhatónak, míg a második készülék első vizsgálatánál a teljes extenzió $\left(0^{\circ}\right)$ vagy annál bármilyen kisebb szögérték volt. A harmadik vizsgálat során szintén a továbbfejlesztett változatot alkalmaztuk, ekkor az 1 . és 5 . nap közötti, röntgenfelvétel alapján meghatározott extenziós szögérték változását mértük.

Az első és a harmadik vizsgálatnál 5\%-os, a második készülék első vizsgálatánál 10 \%-os szignifikancia szint mellett kétmintás t-próbát végeztünk, amely során igazolódott, hogy a HVD-vel kezelt csoportban az elfogadhatónak 
mondható szögek aránya szignifikánsan nagyobb. A harmadik vizsgálatnál a HVD hatása egyértelműen kimutathatóvá vált: a csak CPM-mel kezelt betegeknél minimális romlás, míg a HVD-vel kezelt betegeknél jelentős javulás látható az extenziós szögértékekben.

A HVD készülék második vizsgálatának statisztikailag kevésbé eredményes mivoltához hozzájárulhat az is, hogy a vizsgálatban nem használtunk „sarokpárnát”, így a betegek hajlamosak voltak a kissé kellemetlen kezelést követően a végtagot antalgiás flexiós tartásba helyezni. Bár a HVD kezelés végére minden esetben teljes extenziót értünk el, a betegek a végtag pihentetése érdekében ily módon talán épp a flexiós kontraktúra kialakulásához járulhattak hozzá.

A klinikai alkalmazás során a vizsgált beteganyagnál semmilyen szövődmény nem fordult elő, a kezelést a páciensek jól tűrték, egyetlen esetben sem kellett megszakítanunk a 7 napig tartó kezelést a beteg kezdeményezésére. Néhány esetben fordult elö, hogy a beteg az első kezelés alkalmával még nem kívánta 10 percig használni a készüléket, de ezt a második vagy legkésőbb a harmadik kezelésnél már elérte.

A későbbiekben továbbra is alkalmazzuk a HVD készülék második verzióját a klinikai gyakorlatban, elsősorban a térdízületi protetizálás nehéz eseteinél, valamint olyan betegeknél, akik preoperatív deformitásuknál, extenziós deficitjüknél fogva hajlamosabbak arra, hogy protetizált térdízületükben flexiós kontraktúra alakuljon ki, gyakran csak egy rosszul berögzült tartás vagy antalgiás járásminta miatt. 


\section{IRODALOM}

1. Aderinto J., Brenkel I. J., Chan P.: Natural history of fixed extension deformity following total knee replacement: A prospective fiveyear study. J. Bone Joint Surg. Br. 2005. 87. (7): 934-936. https://doi.org/10.1302/0301-620X.87B7.15586

2. Bennett D., Hanratty B., Thompson N., Beverland D.: Measurement of knee joint motion using digital imaging. Int. Orthop. 2009. 33. (6): 1627-1631. https://doi.org/10.1007/s00264-008-0694-9

3. Draghi F., Danesino G.M., Coscia D., Precerutti M., Pagani C.: Overload syndromes of the knee in adolescents: Sonographic findings. J. Ultrasound. 2008. 11. (4): 151-157. https://doi.org/10.1016/i.jus.2008.09.001

4. Manó S., Pálinkás J., Szabó J., T Nagy J., Bakó K., Csernátony Z.: Application of a vibrating device for the prevention of flexion contracture after total knee arthroplasty. Eur. J. Orthop. Surg. Tr. 2015. 25. (1):167-172. https://doi.orq/10.1007/s00590-014-1466-4

5. Manó S., Pálinkás J., Kiss L., Csernátony Z.: The influence of lateral knee x-ray positioning on the accuracy of full extension level measurements: An in vitro study. Eur. J. Orthop. Surg. Tr. 2012. 22. (3): 245-254. https://doi.org/10.1007/s00590-011-0808-8

6. Quah C., Swamy G., Lewis J., Kendrew J., Badhe N.: Fixed flexion deformity following total knee arthroplasty. A prospective study of the natural history. Knee. 2012. 19. (5): 519-521. https://doi.ora/10.1016/i.knee.2011.09.003

7. Rodriguez-Merchan E. C.: Instability following total knee arthroplasty. HSS Journal. 2011. 7. (3): 273-278.

8. Salter R. B.: The biologic concept of continuous passive motion of synovial joints. The first 18 years of basic research and its clinical application. Clin. Orthop. Relat. Res. 1989. (242): 12-25.

9. Seyler T. M., Marker D. R., Bhave A., Plate J. F., Marulanda G. A., Bonutti P. M., Delanois R. E., Mont M. A.: Functional problems and arthrofibrosis following total knee arthroplasty. J. Bone Joint Surg. Am. 2007. 89. Suppl. 3: 59-69. https://doi.org/10.2106/JBJS.G.00457

10. Szabó J., Bakó K., Manó S., Csernátony Z.: A fájdalom ingerület-vezetés spinális gátlásának elvét felhasználó térdmozgató készülék bemutatása. Biomechanica Hungarica. 2012. 5. (1): 39-43.

11. Ververeli P. A., Sutton D. C., Hearn S. L., Booth R. E., Hozack W. J., Rothman R. R.: Continuous passive motion after total knee arthroplasty. Analysis of cost and benefits. Clin. Orthop. Relat. Res. 1995. (321): 208-215.

\section{Dr. Györfi Gyula}

DEKK Ortopédiai Klinika

4012 Debrecen, Nagyerdei krt. 98.

E-mail: gyorfigyula@yahoo.com 